Revue de l'Institut des langues et cultures

d'Europe, Amérique, Afrique, Asie et Australie

$30 \mid 2018$

Création culturelle et territoires : de l'histoire au mythe, du réel à l'utopie

\title{
A Glimpse of Hope at the End of the Dystopian Century: The Utopian Dimension of Critical Dystopias
}

Une lueur d'espoir à la fin du siècle dystopique : la dimension utopique des

dystopies critiques

\section{Peter Seyferth}

\section{OpenEdition}

Journals

\section{Electronic version}

URL: http://journals.openedition.org/ilcea/4454

DOI: $10.4000 /$ ilcea.4454

ISSN: 2101-0609

\section{Publisher}

UGA Éditions/Université Grenoble Alpes

\section{Printed version}

ISBN: 978-2-37747-033-4

ISSN: $1639-6073$

\section{Electronic reference}

Peter Seyferth, «A Glimpse of Hope at the End of the Dystopian Century: The Utopian Dimension of Critical Dystopias », ILCEA [Online], 30 | 2018, Online since 31 January 2018, connection on 19 April 2019. URL : http://journals.openedition.org/ilcea/4454; DOI : 10.4000/ilcea.4454

This text was automatically generated on 19 April 2019

(C) ILCEA 


\section{A Glimpse of Hope at the End of the Dystopian Century: The Utopian Dimension of Critical Dystopias}

Une lueur d'espoir à la fin du siècle dystopique : la dimension utopique des dystopies critiques

Peter Seyferth

1 Utopia is now 500 years old, and it is still alive and kicking-although it has also been declared dead several times. ${ }^{1}$ Utopia has changed and adapted to its circumstances. We are not living in times of humanist jokes or grand narratives, so old styles of utopia feel quite outdated today. But we are also not living in times where there is no alternative, as some want us to believe, so utopia as a literary imagination of possibilities and alternatives is not outdated at all. I want to show this in the following steps: firstly, I subdivide the literary utopian tradition in several phases. Secondly, I interpret the reallife totalitarian systems as result of the implementation of utopian ideas; this feeds back into a literary utopianism (or rather: anti-utopianism) that places emphasis on totalitarian results of utopia. We know this as the literary dystopia, the alleged nail in the coffin of positive, perfectionist utopia. Thirdly, I give a quick overview of the critical utopias of the 1970s, science-fictional novels that revived the hopeful spirit of utopia while rejecting any notion of perfectionism. Sadly, this phase was quite short-lived, so fourthly I introduce critical utopia's darker twin, the critical dystopia, which is still more hopeful than the classical dystopia and thusly shows that there is a glimpse of hope at the end of the dystopian century. And lastly, I claim that in the new millennium there are ambiguously utopian science fiction novels that should also be understood as critical utopias or critical dystopias. So there is new material for literature analysis that is as rich as the classics of the last 500 years-if we are ready to suspend the desperation and cynicism of the real-life dystopia we live in.

2 I claim that it is useful to divide the literary tradition in several phases. This division is an analytical tool that does not necessarily reflect the author's intentions or interpretations, 
but the scholar's research interest. Let's start with the three classical phases. From Thomas More's Utopia on, many authors described distant fictitious countries, mostly islands, that were fundamentally better than their real contemporary societies. At the beginning, in the first phase, the alternative societies were set somewhere else in the same time, reflecting the vast variety of different human societies as they were reported by travellers in the age of discoveries. The traveller is the typical narrator of these firstphase utopias: he lands at the utopian shore, meets a tourist guide who is also a propagandist and a debater, is convinced by the superior political order of the utopia, and finally reports back in his home country. The political function of these first-phase utopias is comparatively weak: criticism of the real-world contemporary society plus some moral admonition, if not just a humanist jest. It makes you smirk and giggle-and that's it. The second phase is quite similar, with its narrating traveller still made into a convert. The difference is that no-place (ou-topia) is no longer another place, but a future time. The good society becomes something that might come into existence here, if we fight for it. So the function of the utopian text becomes that of a revolutionary goal or a blueprint to be carried out. This reflects the understanding of luminaries that the order of things and people is man-made and can be changed by will. Or by force, if necessary. This insight is typically for pre-revolutionary intellectuals in France and then for many socialists. The most influential of the French utopias was Louis-Sébastien Mercier's L'an 2440, rêve s'il en fut jamais (1770); ${ }^{2}$ the most influential of the socialist utopias was Edward Bellamy's Looking Backward: 2000-1887 (1888). Alas, the empirical truth of revolution is not as beautiful as literature. Not only the French Revolution was quite bloody-the violence of overturning a social order was even an integral part of William Morris's News from Nowhere (1890), his literary answer to Bellamy. The third phase of utopia turns around the perspective and the valuation, thus inventing classical dystopia. Dystopia is described not by a fascinated visitor, but by an inhabitant of an apparent good society that, from the inside, does not look very good at all. For some commenters on utopian thought, this third phase was the final nail in utopia's coffin, turning utopia into anti-utopia and thus killing it.

But the empirical data of utopian studies is utopian texts, and they do still existalthough they do not look like the classical utopias. There has been a fourth phase, called critical utopia, that acknowledges the pitfalls of classical utopia and is decidedly nonperfectionist. This fourth phase was linked to the hopeful times after the 1968 rebellions. As we know, these hopes have been crushed in the rise of neo-liberalism. This is reflected in the more gloomy fifth phase that is not as hopeless than the classical dystopia, although it is still a dystopia, a critical dystopia. ${ }^{3}$ Today I will focus on the critical phases of literary utopianism, especially on the fifth phase that is a model for today's optimistic speculative fiction. The critical phases mostly use the narrative perspective of inhabitants, although a multiplicity of voices becomes more and more conventional, so that there are also travellers and there is much crossing of frontiers.

4 To understand the change from classicism to criticism, one must understand the role of totalitarianism in utopian thought. Classical utopias are complete descriptions of whole societies; thus frequently every aspect of society is prescribed by the utopian plan and enforced by the ruling powers. This is a typical feature of real-world totalitarian systems, who are implementations not of literary but of programmatic utopias. Bolshevism is the realization of the dream of worker's emancipation and egalitarianism. National socialism is the realization of the dream of racial purity and obedience to the "Führer". Classical 
dystopias depict how nightmarish those dreams are. Yevgeny Zamyatin's мы (1924) and George Orwell's Nineteen Eighty-Four (1949) are typical examples that transcend simple criticism of a certain political system: although Zamyatin wrote from a dissident Bolshevik perspective and Orwell's big brother reminds of Hitler, one can also see Stalin in this fictional dictator and every collectivist surveillance society in both novels. It seems that the implementation of any utopian plan turns good intentions into horror. This is also the case with other utopian plans, e.g. neo-liberalism. ${ }^{4}$ Those that turned against big brother became big brothers themselves. The root of anti-humanism in utopia is not collectivism, but the exclusion of utopian alternatives. A plan that forbids the creation of other, differing plans turns totalitarian, even if it adorns itself with the word "liberty" or with other slogans that are as twisted as Orwell's "War is Peace" or "Freedom is Slavery" (Orwell, 1990: 6).

Utopias that are not totalitarian have to make differing plans possible. They are called "critical utopias". Tom Moylan describes the utopian novels of this fourth phase as follows:

A central concern in the critical utopia is the awareness of the limitations of the utopian tradition, so that these texts reject utopia as a blueprint while preserving it as dream. Furthermore, the novels dwell on the conflict between the originary world and the utopian society opposed to it so that the process of social change is more directly articulated. Finally, the novels focus on the continuing presence of difference and imperfection within utopian society itself and thus render more recognizable and dynamic alternatives. (2014: 10)

The most famous example for these critical utopias that do not reject utopianism but perfectionism is Ursula K. Le Guin's The Dispossessed (1974). It is narrated from the perspective of Shevek, an inhabitant of an anarchist utopian planet that is economically and ecologically poor and that deteriorates politically. Shevek is also a traveller that visits the dominant capitalist state on a cold war planet, where he experiences excessive wealth, but also crass poverty. Although to earthlings, this cold war planet looks like a slightly better version of our own planet in the 1970s, it is clearly the dystopian counterpart of the anarchist planet, in spite of the latter desperately needing reform or revolution. ${ }^{5}$ This issue of politics, change, and alternatives in utopian societies is also prominent in Marge Piercy's Woman on the Edge of Time (1976). Connie, an abused and hospitalized woman, visits or dreams or hallucinates a future society that does not abuse women and is also quite anarchistic. She learns that the actuality of this future society depends on her own action in the present; if she does not fight now, the evils of contemporary society will grow even worse. Thus the narrative perspective changes from that of a victim through utopian imagination to that of a political actor whose decisions matter. ${ }^{6}$ A third example is Samuel R. Delany's Triton (1976), where the protagonist travels between planets, social arrangements, and even sex and gender roles quite freely, thus blurring the line between insider and outsider perspective. Although the social order on the moon Triton is very open to all sorts of lifestyles, happiness is not guaranteed, because there is still lovesickness-and then a war breaks out. ${ }^{7}$ By citing Foucault, Delany stressed that his aim was to write not a utopia, but a heterotopia (Delany, 1996: 292; cf. Foucault, 2004: XIX), a different place-but I would argue that, in contrast to classical utopias, critical utopias are quite heterotopian. Both Delany and Le Guin aptly call their utopias "ambiguous", and this assessment is true for all the critical utopias and dystopias. optimistic-that fits the new era of neo-liberalism, religious fundamentalism, climate 
change, and emerging new feudalism. "Critical dystopia" is a term coined by Lyman Tower Sargent (1994: 9), but again Tom Moylan fleshed it out with political commentary and science fiction analysis. He interprets neo-liberal capitalism as an anti-utopian project that tries to exterminate, colonize, or delegitimize utopia. But utopia is quite cunning, so it uses one of the literary devices of anti-utopia, namely dystopia, to re-enter public discourse and give hope to oppositional activists. These critical dystopias "negotiate the necessary pessimism of the generic dystopia with an open, militant, utopian stance that not only breaks through the hegemonic enclosure of the text's alternative world but also self-reflexively refuses the anti-utopian temptation that lingers like a dormant virus in every dystopian account" (Moylan, 2000: 195). And he goes on: "[T] he critical dystopian vision of the 1980s and 1990s took a hard look at the bad new times of contemporary enclosure and, within a sober apprehension of the intensified exploitation and deprivation, endeavored to find traces, scraps, and sometimes horizons of utopian possibility." (2000: 276) Because I think they succeeded in this, I dare to say that there is a glimpse of hope at the end of the dystopian century. In what follows, I will first show how the three science fiction novels Moylan has analyzed revive utopian hope in dystopian settings, and then I will show newer science fiction novels that carry this critical utopian stance into our new millennium.

7 Let us start with Kim Stanley Robinson's 1988 novel The Gold Coast, the middle part of a trilogy that depicts three different versions of a future California. The title coast is not golden but rather a neon light concrete desert, Orange County is one big city sprawl dissected by superhighways-a real 'autopia'. The protagonist Jim McPherson and his friends live a meaningless cyberpunk life full of parties, sex, and drugs. Jim's father tries to conform to the system and develops weapons for a big corporation, but his life also feels pointless because of the corporate hierarchies and the political scheming that thwart his efforts. Jim tries to fight the system by joining a terrorist group that attacks arms manufacturers, but this is also absurd as it becomes clear that the terrorist group is just a sabotage group financed by an economic competitor of the arms manufacturer. So everything seems to be useless-or, to say it with Adorno: "There is no right life in the wrong one." (Adorno, 2005) But Jim discovers the history of Orange County, a necessary rooting or standing ground for becoming a utopia author who can get out of the grip of the futility of cyberpunk life and who can open possibilities for his friends-although he cannot change the system radically. The self-reflexivity of all three California-novels of Robinson makes three different ways of writing history and possible future-history one of the main themes. Critical utopia and critical dystopia are mixed and directly discussed by protagonists. ${ }^{8}$

In Moylan's next example, Octavia E. Butlers 1993 novel Parable of the Sower, society breaks down completely, and a kind of Hobbesian state of nature emerges. Even the powerful corporations with their own cities-the typical villains of the post-totalitarian (or rather neo-totalitarian) dystopias-are no solution, because they enslave their workers. The protagonist of the novel, Lauren Olamina, is a 16 year old girl that tries to flee to Canada, but on the street northwards everybody is a possible murderer and a possible victim. Lauren cannot defend herself by violent means, because her mother took some performance-enhancing drugs during pregnancy, leaving Lauren with hyper-sensibility: she intensely feels every pain she sees. So she is very vulnerable. But she manages to leave this war of all against all. She feels the weaknesses of others, so she can reach out to them and offer mutual help. She strengthens this loose bond by preaching a new religion 
she just invented. So a small group comes into existence and finally succeeds in finding and defending a small outlying territory. So, contrary to Thomas Hobbes' solution (to erect an absolutist giant monster state), the social worst-case scenario is left behind by a union of the weak against the strong. I should add that Butler wrote a sequel, Parable of the Talents (1998), where the strong also band together, erect a fundamentalist dictatorship and try to force Lauren's community back into Christianity by brutal rape and torture. But Lauren's religion has already spread into a network spreading the whole American continent, so this other kind of social worst-case scenario (which resembles Hobbes' sovereign state) cannot be victorious in the long run. ${ }^{9}$

9 Moylan's last example is Marge Piercy's He, She and It (1991). The author of the critical utopia Woman on the Edge of Time sketched out a world ruled by a few mega-corporations, called multis, that run a few domed mega-cities that seem to be the only possible places for decent living, because nature outside the domes is devastated and poisoned. Only the poor live there in huge dangerous slums-the glop-where the only food is some kind of edible mud, made by the corporations and exclusively given to their day labourers. The literary style is again quite cyberpunkish. Piercy discusses multiple topics in this novel: gender possibilities, transhumanism, and the defence of utopian communities against overwhelming powers. There are three kinds of utopian pockets outside the corporation domes: the free cities, the black zone, and the new gangs. The free cities produce specialized commodities for the multis; every multi would love to incorporate the free cities, but this would be disadvantageous for the other multis who thusly prevent their competitors from conquest, resulting in a precarious balance of terror, a.k.a. 'security', for the free cities. One of the cities, Tikva, also uses their own military cyborg. This city is the utopian enclave depicted in most detail: a direct democratic, socialist Jewish city; this cyborg is a weapon that is not only used for the city's security, but it is also a threat for the security because the multis are willing to risk much to get it for their own purposes. The cyborg is also Piercy's literary device to intertextually weave the Golem myth into the novel. The black zone is a post-nuclear-war Israel where apparently no human can live; but surviving women live there in caves, creating not only a new utopian community but new radiation-resistant bodies, thus entering the stage of transhumanism. Then there are the criminal gangs in the glop who make life there even more miserable. But new gangs emerge. They do not act as warlords but strive towards egalitarian revolutionary objectives. They even invent their own artificial food, making it possible to strike against the multis without starving. All three utopian groups are in extreme danger and only have a chance when they help each other. It remains open if they will succeed-and how much violence they should use.

10 So all three critical dystopias warn against a capitalist-run world, the new kind of totalitarianism after the demise of Soviet style Communism. But they all show that there is still hope, and that hope lies in utopian imagination and in real-world mutual aid.

11 I claim that some science fiction novels of the new millennium are as ambiguously utopian as both the critical utopias of the 1970s and the critical dystopias of the 1980s and 1990s. I want to show you three of them. As far as I know, they have not yet been discussed by utopia scholars, so they may be really new to you.

12 My first example is Chris Carlsson's 2004 novel After the Deluge. Chris Carlsson is an activist with the Critical Mass group in San Francisco, and in his novel he depicts a future San Francisco after climate change and after a successful revolution where Carlsson's ideals have been achieved. The main themes are ecology and economy. Ecologically, 
San Francisco has been made very green: no more cars but only bikes, strips of wilderness through the city, our copper and electricity based internet has been replaced by a biological internet based on genetically modified vine. And science is strictly controlled by the deliberative direct democracy (or rather: political anarchism) of the city-this is necessary because profit-oriented science has killed off most people some decades before, sparing only hillbillies and potheads; and now the scientists want to genetically alter dolphins. So this is one field of heated political debate in the novel. The other main topic is work arrangements in San Francisco's gift economy. One does not have to work much for a living, but when you work, good quality of the produced goods is expected; and this also leads to disputes. After the Deluge is remarkable because it mixes the two typical perspectives of utopias and dystopias: on the one hand, there is a utopian traveller, Eric, who visits San Francisco, settles down and brims over with enthusiasm for the way things are there-he becomes not only a convert, but even something like an anarchist policeman that wants to protect San Francisco from terrorist attacks. On the other hand, there is the dystopian inhabitant, Nwin, who grew up in San Francisco and hates it. He dreams of the 'real freedom' that, as he supposes, can be found in the ideas of the ReaganPinochet-Army he wants to join. He is the terrorist arsonist, Erics adversary. While reading After the Deluge, one can understand both, although the positively utopian Eric is more likeable.

The next example is Neal Stephenson's epic and philosophical novel Anathem from 2008. It can be read without taking it as utopia, but it is certainly a very special and thoughtful novel. It even has been reviewed in Nature, the famous science journal, which is a rare honour. The novel discusses scientific and philosophical concepts like quantum mechanics, parallel universes and the nature of consciousness. And it invents a new language. So it is difficult to read-but very rewarding, especially for utopia scholars. From this viewpoint, Anathem presents itself as critical dystopia. It is told from the perspective of the inhabitant of a monastery-like community that allows its members to go to the saecular world only once in a year, or once in a decade, or even only once in a century. There are strict rules, hierarchical bureaucracy, nasty punishments, asceticism, and the high technology that everyone can use outside this monastery is forbidden for the inhabitants. This is quite typical for classical utopias and dystopias: they are very often quite monastical. Outside there is political change, religious conflict, stupidity, while the monastery is an island of stability. The monastery is not religious, but rather scientific, mathematic, philosophic. As long as one follows the general rules, one can do what one wishes. After all, it is not so bad, despite of being quite austere. And then something happens from the outside, and the protagonist, Fraa Erasmas, has to save not only the monastery, but the world-the world that he is allowed to visit only every ten years. In the course of the adventure, the walls between monastery and saecular world and the strict rules are questioned, and a new era might arise-if the world is not destroyed. Anathem is a critical utopia not because it criticizes capitalism and the state (they are in the saecular world), but it criticizes the utopian enclave and shows how it can change to the better, through the actions of an individual that repeatedly breaks the rules and finds friends that help him.

Now the last example, Margaret Killjoy's A Country of Ghosts (2014). Unlike Stephenson's Anathem, it is a quite short book. Like Carlsson's After the Deluge, it is informed by the author's activist experiences. The utopian aspect of this steampunk novel consists of the kinds of organization of the mountain people Hron, their decision procedures, their views 
on ownership, and their structures of accountability. They all reflect the practices of today's altermondialists, anarchists, and Occupy campers. A Country of Ghosts resembles many classical and critical utopias: the Hron are exiles just like the anarchists in Le Guin's The Dispossessed. They are visited by the utopian traveller Dimos Horacki, who is a journalist just like William Weston in Ernest Callenbach's Ecotopia (1975) or like Will Farnaby in Aldous Huxley's Island (1962). Like them, he sympathizes with the utopians and eventually joins them. This also resembles Louis-Armand de Lahontan's Supplement aux Voyages ou Dialogues avec le sauvage Adario (1703), where the reader is advised not to join the Hron, but the Hurons. But the utopian mountain people do not live in peace: an imperial army attacks brutally. The journalist Dimos is embedded in this army and has to support it by writing compliant press articles. So at the beginning of the novel, we have the insider perspective of a dystopian inhabitant. Then, after he defects to the Hron, his perspective changes into that of a utopian traveller and finally a fellow combatant. The whole story is actually a part of the resistant war effort. It ought to win over the readers, to make them leave the empire and join the utopian enclave that revolutionarily fights the system. Actually, this does not only seem to be the intradiegetic wish of the journalist Dimos, but also the extradiegetic objective of the novel's author, Margaret Killjoy. Thus, the most recent utopia I could find tries to have impact on the world, just like some of the classical utopias of the second phase, but with a critical twist that shows the weakness and precarity of a utopian enclave that stands in direct opposition to a powerful capitalist state.

And so I close with a few remarks. In my article I have not delved deeply into any of these texts. They all deserve more critical analysis. But my intention was to show that utopia is not dead, so an overview approach seemed to be reasonable. There are more texts like these. Utopia is still a tool of imagination, a mirror of hope, and an expression of desire. We live in bleak times, so utopia has to disguise itself as dystopia. This is not bad, because there is a dystopian nucleus in every utopia. But I wanted to show that there is also a nucleus of utopia in dystopia. Hopefully even in the very real dystopia we live in today.

\section{BIBLIOGRAPHY}

ADoRno Theodor W. (2005), Minima Moralia [1951] (trans. Dennis Redmond), <www.marxists.org/ reference/archive/adorno/1951/mm/ch01.htm> (accessed 6 September 2016).

BeLlamy Edward (2007), Looking Backward, 2000-1887 [1888], Oxford, New York: Oxford University Press.

BUtLer Octavia E. (2007a), Parable of the Sower [1993], New York, Boston: Grand Central Publishing. BUTLER Octavia E. (2007b), Parable of the Talents [1998], New York, Boston: Grand Central Publishing.

CALlENBACH Ernest (2014), Ecotopia. 40th Anniversary Epistle Edition [1975], Berkeley: Heyday. 
CARLSSON Chris (2004), After the Deluge. A Novel of Post-Economic San Francisco, San Francisco: Full Enjoyment Books, <www.chriscarlsson.com/wp-content/uploads/2012/03/deluge5_fixed-forpdf.pdf>.

DELANY Samuel R. (1996), Trouble on Triton [1976], Hanover, London: Wesleyan University Press. FEST Joachim (1991), Der zerstörte Traum. Vom Ende des utopischen Zeitalters, Berlin: Siedler.

FouCAULT Michel (2004), The Order of Things [1966], London, New York: Routledge.

FRIEDMAN Milton (2002), Capitalism and Freedom. Fortieth Anniversary Edition [1962], Chicago:

University of Chicago Press.

FUKUYAMA Francis (1993), The End of History and the Last Man [1989/1992], New York: Avon Books.

HAYEK Friedrich August von (2007), The Road to Serfdom. Text and Documents. The Definitive Edition [1944], Chicago: University of Chicago Press.

HuXLEY Aldous (2009), Island [1962], New York: Harper Perennial.

KiLLjoy Margaret (2014), A Country of Ghosts, New York: Combustion Books.

KoSELLECK Reinhart (1985), “Die Verzeitlichung der Utopie”, W. Voßkamp (ed.), Utopieforschung. Interdisziplinäre Studien zur neuzeitlichen Utopie, Frankfurt am Main: Suhrkamp, 3, 1-14.

Lahontan Baron de (1905), New Voyages to North-America [1703], Chicago: A. C. McClurg \& Co.

LE GuIN Ursula K. (1985), Always Coming Home, New York: Harper \& Row.

LE GuIN Ursula K. (1989), “A Non-Euclidean View of California as a Cold Place to Be”, U. K. Le Guin, Dancing at the Edge of the World. Thoughts on Words, Women, Places [1982], New York: Grove Press, 80-100.

LE GuIN Ursula K. (1994), The Dispossessed. An Ambiguous Utopia [1974], New York: Harper Prism.

LE Guin Ursula K. (2005), “A Response, by Ansible, from Tau Ceti”, L. Davis \& P. Stillman (eds), The New Utopian Politics of Ursula K. Le Guin's The Dispossessed [2004], Lanham et al.: Lexington Books, 305-308.

LEIBACHER-OUVRARD Lise (2000), "Épigone, Histoire du siècle futur (1659): première uchronie et politique-fiction nostalgique”, French Forum, 25(1), 23-41.

MERCIER Louis-Sébastien (2015), L'an deux mille quatre cent quarante. Rêve s'il en fût jamais [1770], Bruxelles: UltraLetters Publishing.

MORRIS William (2009), News from Nowhere [1890], Oxford, New York: Oxford University Press.

MoYLAN Tom (2000), Scraps of the Untainted Sky. Science Fiction, Utopia, Dystopia, Boulder: Perseus.

MoYlan Tom (2014), Demand the Impossible. Science Fiction and the Utopian Imagination [1986], Bern: Peter Lang.

ORWELL George (1990), Nineteen Eighty-Four [1949], London: Penguin Books.

PIERCY Marge (1993), He, She and It [1991], New York: Ballantine Books.

PIERCY Marge (2016), Woman on the Edge of Time [1976], New York: Ballantine Books.

PURE Michel (2015), Épigone, histoire du siècle futur (1659): édition établie par Lise Leibacher-Ouvrard et Daniel Maher [1659], Paris: Hermann.

RoBINSON Kim Stanley (1995), The Gold Coast [1988], New York: Orb Books. 
SARGENT Lyman Tower (1994), “The Three Faces of Utopianism Revisited”, Utopian Studies, 5(1), 137.

SEYFERTH Peter (2008), Utopie, Anarchismus und Science Fiction. Ursula K. Le Guins Werke von 1962 bis 2002, Münster/Berlin: Lit.

SOMAY Bülent (1984), “Towards an Open-Ended Utopia”, Science Fiction Studies, 11(1), 25-38.

STEPHENSON Neal (2009), Anathem, New York: HarperCollins.

ZAMYATIN Yevgeny (1993), We [1924], New York: Penguin Books.

\section{NOTES}

1. There are two typical reasons to declare utopia dead: either utopia is too bad for this world, or this world is too good for utopia. The first type understands the totalitarian systems as pinnacle of utopian thinking; an example would be Fest (1991). The second type understands the posttotalitarian world as pinnacle of social development, making any visions of a better society superfluous; an example would be Fukuyama (1993).

2. Although this was by no means the first of the French future-utopias, as Reinhart Koselleck claimed in his influential distinction of "Raumutopie" (utopias of place, the first phase of classical utopias) and "Zeitutopie" (utopias of time, the second phase of classical utopias) (Koselleck, 1985). I use Koselleck's distinction here, but I also have to mention Michel Pure's Épigone, histoire du siècle futur (1659), 111 years older than Mercier's utopia.

3. I use the terms "critical utopia" and "critical dystopia" in Tom Moylan's vein (2014 and 2000, respectively; see below). Others have accepted or even coined the terms (e.g. Sargent, 1994: 8-9) or used different terms like "open-ended utopia" to refer to the same phenomenon (Somay, 1984: 26).

4. I would argue that in spite of their criticism of planning (notorious: Friedrich August von Hayek's Road to Serfdom [1944]), neo-liberalism's forefathers had big plans themselves. The most widely read neo-liberal utopian text is Milton Friedman's Capitalism and Freedom (1962).

5. Moylan discusses The Dispossessed in his fifth Chapter (2014: 87-114). Although this is Le Guin's most prominent utopia, it is not the pinnacle of her utopian fiction. She criticised it's still too traditional basic principles (Le Guin, 1989), wrote the new critical utopia Always Coming Home (1985) and bewailed that The Dispossessed is still treated as her only utopia (Le Guin, 2005). Cf. Seyferth (2008: 259-326).

6. Moylan discusses Woman on the Edge of Time in his sixth chapter (2014: 115-147).

7. Moylan discusses Triton, which in later edition was renamed into Trouble on Triton, in his seventh chapter (2014: 149-185).

8. Moylan discusses The Gold Coast in his seventh chapter (2000: 203-222).

9. Moylan discusses Parable of the Sower and Parable of the Talents in his seventh chapter (2000: 223-246). 


\section{ABSTRACTS}

The 20th century demonstrated that the realization of utopian plans often fosters totalitarianism. Fantastic, speculative literature mirrored this by turning from utopia to dystopia. In the hopeful 1970s, critical utopian texts revived the hope for a better world in a more complex fashion that replaced perfectionism with ambiguity and self-reflection. But neoliberalism prevailed and other utopian hopes declined again. But a new kind of utopian text emerged in the 1980s and 1990s: the critical dystopia. Novels like Kim Stanley Robinson's The Gold Coast (1988), Marge Piercy's He, She and It (1991), and Octavia E. Butler's Parable of the Sower (1993) depict horrible capitalist dystopian societies that almost crush the emancipatory hopes of resistance groups. But their utopian desire is not completely futile. This glimpse of hope also characterizes ambiguously utopian science fiction texts of the new millennium, e.g. Chris Carlsson's After the Deluge (2004), Neal Stephenson's Anathem (2008), and Margaret Killjoy's A Country of Ghosts (2014).

Le $\mathrm{xx}^{\mathrm{e}}$ siècle a montré que la réalisation des programmes utopiques nourrit fréquemment le totalitarisme. La littérature fantastique et spéculative a reflété cette tendance en passant de l'utopie à la dystopie. Dans l'enthousiasme caractéristique des années 1970, des textes utopiques critiques ranimèrent l'espoir d'un monde meilleur dans le cadre d'une approche plus complexe qui substituait l'ambiguïé et l'introspection au perfectionnisme utopique. Mais la domination du néo-libéralisme a emporté les espoirs renouvelés de l'utopie. Cependant, une nouvelle variété utopique vit le jour dans les années 1980 et 1990 : la dystopie critique. Des romans comme The Gold Coast (1988) de Kim Stanley Robinson, He, She and It de Marge Piercy (1991) ou encore The Parable of the Sower d'Octavia E. Butler décrivent d'horribles sociétés capitalistes dystopiques qui anéantissent presque les espoirs d'émancipation des groupes de résistants. Mais leur désir d'utopie n'est pas réduit à la futilité. C'est cette lueur d'espoir qui caractérise aussi de façon ambiguë des textes de science fiction utopique du nouveau millénaire comme After the Deluge de Chris Carlsson (2004), Anathem de Neal Stevenson (2008) et A Country of Ghosts de Margaret Killjoy (2014).

\section{INDEX}

Keywords: fantastic literature, utopia, dystopia, capitalism, neo-liberalism, resistance, critical utopias

Mots-clés: littérature fantastique, utopie, dystopie, capitalisme, néo-liberalisme, résistance, utopies critiques

\section{AUTHOR}

\section{PETER SEYFERTH}

FernUniversität Hagen 